IBIMA Publishing

Journal of Southeast Asian Research

http://www.ibimapublishing.com/journals/JSAR/jsar.html

Vol. 2013 (2013), Article ID 331173, 17 pages

DOI: $10.5171 / 2013.331173$

Research Article

\title{
Enterprise Business Intelligence Maturity Model: Case Study in Financial Industry
}

\author{
Min-Hooi Chuah and Kee-Luen Wong \\ Universiti Tunku Abdul Rahman, Perak, Malaysia
}

Correspondence should be addressed to: Min-Hooi Chuah; chuahmh@utar.edu.my

Received 9 January 2013; Accepted 20 May 2013; Published 30 September 2013

Copyright (C) 2013 Min-Hooi Chuah and Kee-Luen Wong. Distributed under Creative Commons CC-BY 3.0

\begin{abstract}
In new era, Business Intelligence (BI) is important particularly for many chief Information Officers (CIOs). BI especially plays an essential role in organizations and allows managers to analyze business performance in a convenient way and hence, improve decision making. Despite knowing the importance of BI implementation, many organizations still struggle to achieve this especially in financial companies. This paper proposes an Enterprise Business Maturity Model (EBI2M) and evaluates it in one of the financial companies in Malaysia. Preliminary result indicates that the company does not achieve in term of data warehouse, metadata management, knowledge management and performance measurement perspective. Therefore, an EBI2M is used to provide symmetric guidelines for these companies to improve the BI implementation in the future.
\end{abstract}

Keywords: Business Intelligence, maturity model.

\section{Introduction}

According to Turban et. (2011), Business Intelligence can be defined as "a set of methodology that turns the raw data to useful information to the right people, and right time". BI can be defined as "black box" that transforms the raw data from data source to useful information and displays the graphical representation to allow the user view business performance and hence improve decision making.

There has been a fast growing interest in $\mathrm{BI}$ area in the new century, but the success for implementing BI is still questionable (Ang \& Teo 2000; Lupu et.al (1997); Computerworld (2003)). Lupu et.al (1997) reported that about $60 \%-70 \%$ of business intelligence applications fail due to the technological, organizational, cultural and infrastructure issues. Furthermore, EMC Corporation argued that many BI initiatives have failed because tools weren't accessible to end users and the result of not being able to meet the end users' need effectively. Computerworld (2003) stated that BI projects fail because of the failure to recognize BI projects as cross organizational business initiatives, unengaged business sponsors, unavailable or unwilling business representatives, lack of skilled and available staff, no business analysis activities, no appreciation of the impact of dirty data on business profitability and no understanding of the necessity and the use of meta-data. A maturity model is needed to provide systematic maturity guidelines and readiness assessment for such 
resourceful initiative. While there are many BI maturity models in the literature, most of them do not consider all factors affecting BI. Some of BI maturity models focus on the technical aspect and some of the models focus on business point of view.

Therefore, this research seeks to bridge this missing gap between academia and industry, through a thorough formal study of the key dimensions and associated factors pertaining to Enterprise Business Intelligence (EBI). It aims to investigate the dimensions and associated factor for each maturity level. The remainder of this paper has been structured as follows; the next section discusses the review of $\mathrm{BI}$ maturity models, the third section then outlines and discusses the proposed EBIM model, then followed by a case study in one of the financial companies.

\section{Literature Review}

There are many Business Intelligence maturity models developed by different authors such as Business intelligence Development Model (BIDM), TDWI's maturity model, Business Intelligence Maturity Hierarchy, Hewlett Package Business Intelligence Maturity Model, Gartner's Maturity Model, Business Information Maturity Model, AMR Research's Business Intelligence/ Performance Management Maturity Model, Infrastructure Optimization Maturity Model and Ladder of business intelligence (LOBI). This section reviewes several of business intelligence maturity models by different authors. 
Table 1: Summary of Various BI Maturity Models

\begin{tabular}{|c|c|}
\hline y models & escription \\
\hline $\begin{array}{l}\text { TDWI's maturity } \\
\text { model }\end{array}$ & $\begin{array}{l}\text { - The maturity assessment tool is available in the web to evaluate Bl's maturity level } \\
\text { as well as documentation. } \\
\text { - Concentrates on the technical viewpoints especially in data warehouse aspect. } \\
\text { - Can be improved on business viewpoint especially from the cultural and } \\
\text { organizational view. }\end{array}$ \\
\hline $\begin{array}{l}\text { s } \\
\text { ence } \\
\text { y Hierarchy }\end{array}$ & $\begin{array}{l}\text { - Applied the knowledge management field } \\
\text { - Author constructed maturity levels from a technical point of view but can be } \\
\text { considered as incomplete. } \\
\text { - The documentation of this model is in the form of one paper and it is not enough for } \\
\text { maturity level assessment. }\end{array}$ \\
\hline $\begin{array}{l}\text { Hewlett Package } \\
\text { Business } \\
\text { Intelligence } \\
\text { Maturity Model }\end{array}$ & $\begin{array}{l}\text { ty levels from business technical aspect. } \\
\text { and needs to improve to add more technical aspects such as data- } \\
\text { lytical aspects. }\end{array}$ \\
\hline $\begin{array}{l}\text { Gartner's Maturity } \\
\text { Model }\end{array}$ & $\begin{array}{l}\text { - Used to evaluate the business maturity levels and maturity of individual } \\
\text { departments. } \\
\text { - Provides more non technical view and concentrates on the business technical } \\
\text { aspect. } \\
\text { - Well documented and can be searched easily on the Web. } \\
\text { - The assessment offers the series of questionnaire to form of spreadsheet. }\end{array}$ \\
\hline $\begin{array}{l}\text { Business } \\
\text { Information } \\
\text { Maturity Model }\end{array}$ & $\begin{array}{l}\text { ocumented with the series of questionnaire to assist the users to perform self } \\
\text { g. } \\
\text { jer, criteria to evaluate the maturity level are not well defined. }\end{array}$ \\
\hline $\begin{array}{l}\text { AMR Research's } \\
\text { Business } \\
\text { Intelligence/ } \\
\text { Performance } \\
\text { Management } \\
\text { Maturity Model }\end{array}$ & $\begin{array}{l}\text { - Concentrates on the performance management and balanced scorecard rather than } \\
\text { business intelligence. } \\
\text { - Not well documented and the criteria to evaluate the maturity level are not well } \\
\text { defined. } \\
\text { - No questionnaire to evaluate the maturity levels and is very hard to analyse the } \\
\text { model }\end{array}$ \\
\hline $\begin{array}{l}\text { ure } \\
\text { on } \\
\text { lodel }\end{array}$ & $\begin{array}{l}\text { - Focuses on the measurement of the efficiency of reporting, analysis and data- } \\
\text { warehousing and is not complete in the business intelligence area } \\
\text { - Discusses the products and technologies rather than business point of view } \\
\text { - Not well documented and the criteria to evaluate the maturity level are not well } \\
\text { defined. }\end{array}$ \\
\hline $\begin{array}{l}\text { Ladc } \\
\text { intel }\end{array}$ & $\begin{array}{l}\text { - Applies the knowledge management field } \\
\text { - Author constructed maturity levels from a technical point of view but can be } \\
\text { considered as incomplete. } \\
\text { - Not well documented and the criteria to evaluate the maturity level are not well } \\
\text { defined. }\end{array}$ \\
\hline $\begin{array}{l}\text { Business } \\
\text { intelligence } \\
\text { Development } \\
\text { Model (BIDM) }\end{array}$ & $\begin{array}{l}\text { - Not well documented and the criteria to evaluate the maturity level are not well } \\
\text { defined. } \\
\text { - Concentrates on the technical aspects rather than business point of view }\end{array}$ \\
\hline
\end{tabular}


Table 1 above depicts a summary of various business intelligence maturity models. As shown in the table 1 , the majority of the models does not focus on the business intelligence as entire which some of the models focus on the technical aspect and some of the models focus on business point of view. For example, TDWI's model only concentrates on the data warehousing while Business Intelligence Maturity Hierarchy only concentrates on knowledge management. It is not complete to represent business intelligence. We know that business intelligence covers not only data warehousing, but also business performance, balanced scorecard, analytical components. In addition, the documentation of some maturity models above is not well defined and they do not provide any guidelines or questionnaire to evaluate maturity levels.

\section{Proposed Framework}

Based on the literature review above, the majority of the models does not focus on the business intelligence as entire which some of models focus on the technical aspect and some of the models focus on business point of view. If the organizations want to know exactly their business intelligence maturity levels as a whole, they have to use multiple models and that is time consuming. Hence, there is a need to have an integrated maturity model to combine existing different maturity model and questionnaires, and evaluation criteria should be provided. In view of this, an Enterprise Business Intelligence Maturity Model (EBI2M) is proposed.

The proposed EBI2M consists of two representations: staged representation and continuous representation. The staged representation consists of five levels namely; initial, managed, defined, quantitatively managed and optimizing; all of which are adapted from CMMI maturity levels. There are thirteen key process areas, namely; change management, culture, strategic management, people, performance measurement, balanced scorecard, information quality, data warehousing, master data management, metadata management, analytical, infrastructure and knowledge management.

The continuous representation consists of thirteen dimensions (change management, culture, strategic management, people, performance measurement, balanced scorecard, information quality, data warehousing, master data management, metadata management, analytical, infrastructure and knowledge management) that adapted from various literature reviews such as Sen et.al (2006); Baskarada et.al (2006); Dyche and Levy (2009); Davenport and Harris (2007); Ferris (2008); Grembergen and Saull (2001); Kochilar (2000); Wettstein and Kueng (2002); Davis et.al (2006) ; Prosci (2004) ; Arveson et.al (2010) as well as Smith and Finger (2004). 


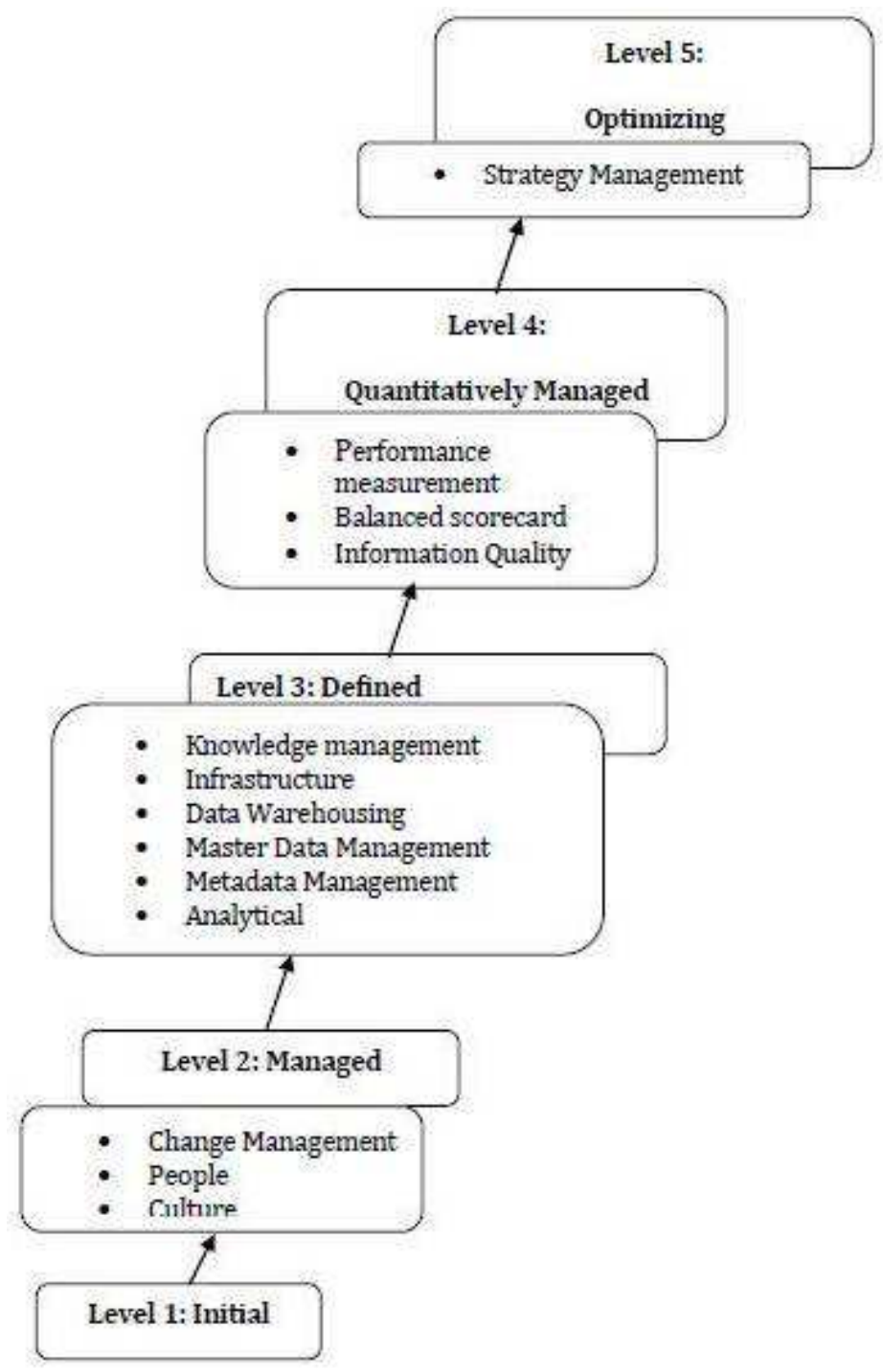

Fig1: Preliminary Enterprise Business Intelligence Maturity Model (EBI2M)

Developed by author

\section{Methodology}

The proposed Enterprise Business Intelligence Maturity model (EBI2M) was applied in the financial company in order to evaluate the maturity of BI implementation. This case study was prepared following a series of detailed interviews with staff, the collection of supporting documents and follow up interviews to clarify specific issues arising from the analysis of case study materials. 
Table 2: Case Study's Participate

\begin{tabular}{|c|c|l|c|c|}
\hline Company & Industry & \multicolumn{1}{|c|}{$\begin{array}{c}\text { Positions of } \\
\text { Interviewers }\end{array}$} & $\begin{array}{c}\text { Size of } \\
\text { employees }\end{array}$ & $\begin{array}{c}\text { Years of } \\
\text { experiences in BI }\end{array}$ \\
\hline $\mathrm{A}$ & Insurance & $\begin{array}{l}\text { CIO, Business } \\
\text { Analysts }\end{array}$ & 1000 to 5000 & $\begin{array}{c}\text { More than } 10 \\
\text { years }\end{array}$ \\
\hline
\end{tabular}

Company $\mathrm{A}$ is a very known insurance company in Malaysia. The headquarter is located in Kuala Lumpur and has more than 20 branches and outlets across Malaysia. Currently, the employees of the company are approximately 1000-5000. In 2011, the total revenue generated by company $\mathrm{A}$ is more than RM 200 million. Company A consists of MIS department which handles IT related jobs. Company A has more than ten years experience of using Business Intelligence (BI) application and has 11-15 persons to handle BI applications. The BI tools used in company $A$ are Oracle, SAP and Informatics.

\section{Results and Discussions}

The respondents were instructed to rate their companies' capabilities of BI implementation from level 0-5.

Below are the results of company A capabilities of BI implementation on thirteen dimensions

\section{Data Warehouse Perspective}

- The company has data warehouse and span across the enterprise.

- The company applied extract/transform/load (ETL) processes.

- The company uses automatic extraction all business data from various sources.

- The company has data marts and data warehouses which allow user to access information.
- The data in ETL are extracted and transformed on a consistent basis.

- The data platforms that the company used are integrated into a common, company platform.

- The data warehouse in the company is not integrated with external parties, such as suppliers, customers or partners.

- The information in the company's data warehouse is updated daily.

- The redundancy of dart mart in the company is seemed minimal.

- The data warehouse of the company is able to perform automatic capturing and delivery of metadata.

- The company has no strict rules or procedures for data management and is limited to system administrator.

- The company has semi automated system for integrating data from different sources.

- The enterprise data is available to any department that needs it.

- The data standard and definitions are set at enterprises level. 
Table 3: Company A's Data Warehouse Perspective

\begin{tabular}{|l|l|l|c|}
\hline $\begin{array}{l}\text { Key process } \\
\text { area }\end{array}$ & Criteria & Appraisal Measures & $\begin{array}{c}\text { Capability levels } \\
\text { (Please Rate 0-5) }\end{array}$ \\
\hline $\begin{array}{l}\text { Data } \\
\text { Warehouse }\end{array}$ & ETL & $\begin{array}{l}\text { - Ability to read directly from your data } \\
\text { source }\end{array}$ & 3 \\
\hline \begin{tabular}{l} 
- Automated capturing and delivery of \\
metadata \\
\cline { 3 - 4 }
\end{tabular} & $\begin{array}{l}\text { - Easy to use interface for the developer } \\
\text { and the functional user }\end{array}$ & 2 \\
\cline { 2 - 4 } & Data Mart & $\bullet$ No redundancy of data mart & 2 \\
\hline
\end{tabular}

\section{Master Data Management Perspective}

- The company is able to combine data residing in different sources and provides users with a unified view of these data.

- The company is not able to establish consistency among data from a source to target data storage and vice versa and continuous harmonization of the data over time.

- The company is able to ensure that multiple versions of data are synchronized.
- The company is able to search the data by tagging it with keywords, descriptions or assigning it to a category.

- The data in the company is able to move from disk files from one folder (or computer) to another with specific access right.

- The company is able to collect master data from several systems at a central location and groups of individuals that is similar in specific ways relevant into several categories.

Table 4: Company A's Master Data Management (MDM) Perspective

\begin{tabular}{|c|c|c|c|}
\hline Key process area & Criteria & Appraisal Measures & $\begin{array}{l}\text { Capability levels } \\
\text { (Please Rate 0-5) }\end{array}$ \\
\hline \multirow{8}{*}{$\begin{array}{l}\text { Master Data } \\
\text { Management } \\
(\text { MDM) }\end{array}$} & \multirow[t]{3}{*}{$\begin{array}{l}\text { Data Integration } \\
\text { Synchronization }\end{array}$} & $\begin{array}{l}\text { - Combining data residing in different sources and } \\
\text { providing users with a unified view of these data }\end{array}$ & 3 \\
\hline & & $\begin{array}{l}\text { - Establishing consistency among data from a source to } \\
\text { a target data storage and vice versa and the continuous } \\
\text { harmonization of the data over time }\end{array}$ & 2 \\
\hline & & -Ensuring multiple versions of a data are synchronized & 2 \\
\hline & \multirow[t]{2}{*}{ Data Profiling } & $\begin{array}{l}\text { - Ability to find out whether existing data can be easily } \\
\text { used for other purposes }\end{array}$ & 2 \\
\hline & & $\begin{array}{l}\text { - The ability to search the data by tagging it with } \\
\text { keywords, descriptions, or assigning it to a category }\end{array}$ & 3 \\
\hline & \multirow[t]{2}{*}{ Data Migration } & $\begin{array}{l}\text { - Ability of data on the old system to be mapped to the } \\
\text { new system }\end{array}$ & 3 \\
\hline & & $\begin{array}{l}\text { - Ability of data to move from disk files from one folder } \\
\text { to another }\end{array}$ & 0 \\
\hline & $\begin{array}{l}\text { Data Consolidation } \\
\text { Segmentation }\end{array}$ & $\begin{array}{l}\text { - Ability to collect master data from several systems at a } \\
\text { central location and groups of individuals that are } \\
\text { similar in specific ways relevant into several categories } \\
\text { such as age }\end{array}$ & 3 \\
\hline
\end{tabular}




\section{Metadata Management Perspective}

- The company has no business metadata, technical metadata and operational metadata.

- The company does not implement any IT architecture for capturing and using business, technical and operational metadata.

- The company is able to define business rule for manipulating, transforming, calculating and summarizing.
- The company is able to provide information regarding configuration, tools and programs.

- The company is able to provide information regarding change and update activity, archiving, backup and usage statistics.

Table 5: Company A's Metadata Management Perspective

\begin{tabular}{|l|l|l|c|}
\hline $\begin{array}{l}\text { Key process } \\
\text { area }\end{array}$ & Criteria & Appraisal Measures & $\begin{array}{c}\text { Capability levels } \\
\text { (Please Rate 0-5) }\end{array}$ \\
\hline $\begin{array}{l}\text { Metadata } \\
\text { management }\end{array}$ & Business Metadata & $\begin{array}{l}\text {-Ability to define business rule for } \\
\text { manipulating, transforming, calculating and } \\
\text { summarizing }\end{array}$ & 3 \\
\cline { 2 - 4 } & Technical Metadata & $\begin{array}{l}\text {-Ability to provide information regarding } \\
\text { configuration, tools and programs }\end{array}$ & 2 \\
\cline { 2 - 4 } & Operational Metadata & $\begin{array}{l}\text { - Ability to provide information regarding } \\
\text { change and update activity, archiving, backup } \\
\text { and usage statistics }\end{array}$ & 2 \\
\hline
\end{tabular}

\section{Knowledge Management Perspective}

- The company is able to capture tacit knowledge.

- There is no tacit knowledge captured at the enterprise level to enable further learning.

- The company allows knowledge to be collated from different experts via Sharepoint.

- The company allows knowledge to be validated and maintained through forum and training.
- Knowledge in the company is shared across the enterprise through forum or training or corporate portal.

- Knowledge in the company can be created through the way of people's doing things or developing something.

- The new knowledge in the company can be identified and represented in a convenient way but for certain context.

- Knowledge in the company cannot be put in context so that it is actionable.

- Knowledge in the company can be stored on a knowledge repository via corporate portal to let organization access it. 
Table 6: Company A's Knowledge Management Perspective

\begin{tabular}{|l|l|l|c|}
\hline $\begin{array}{l}\text { Key process } \\
\text { area }\end{array}$ & Criteria & Appraisal Measures & $\begin{array}{l}\text { Capability levels } \\
\text { (Please Rate 0-5) }\end{array}$ \\
\hline $\begin{array}{l}\text { Knowledge } \\
\text { management }\end{array}$ & Knowledge creation & $\begin{array}{l}\text { - Knowledge can be created through the } \\
\text { way of people's doing things or } \\
\text { developing something }\end{array}$ & 2 \\
\cline { 2 - 4 } & Knowledge Capturing & $\begin{array}{l}\bullet \text { New knowledge should b e } \\
\text { identified and represented in a } \\
\text { convenient way }\end{array}$ & 1 \\
\cline { 2 - 4 } & Knowledge Refining & $\begin{array}{l}\bullet \text { Knowledge must be put in context so } \\
\text { that it is actionable. }\end{array}$ & 0 \\
\cline { 2 - 4 } & Knowledge Storing & $\begin{array}{l}\text { - Knowledge must be stored in a } \\
\text { knowledge repository to let } \\
\text { organization access it }\end{array}$ & 1 \\
\hline
\end{tabular}

\section{Infrastructure Perspective}

- The company has centralized and enterprise levels infrastructure.

- The company provides improvement ideas campaign and daily operational feedback to improve operational systems.
- The partners, suppliers and customers have interactive role in the company's information architecture.

Table 7: Company A's Infrastructure Perspective

\begin{tabular}{|l|l|l|c|}
\hline $\begin{array}{l}\text { Key process } \\
\text { area }\end{array}$ & Criteria & Appraisal Measures & $\begin{array}{c}\text { Capability levels } \\
\text { (Please Rate 0-5) }\end{array}$ \\
\hline Infrastructure & Networking & $\bullet$ Centralized and enterprise levels & 3 \\
\hline
\end{tabular}

\section{Analytical Perspective}

- The company uses analytical or OLAP tools.

- The company is able to support Ad hoc reporting (development of new reports).

- The OLAP or analytical tool in the company is able to support historical comparison/treading.
- The company is able to perform drill down back to the source Data Base tables.

- The company is able to do ad hoc complex calculations (@ report level and cube level). 
Table 8: Company A's Analytical Perspective

\begin{tabular}{|l|l|l|c|}
\hline $\begin{array}{l}\text { Key } \\
\text { process }\end{array}$ & Criteria & Appraisal Measures & $\begin{array}{c}\text { Capability levels } \\
\text { (Please Rate 0-5) }\end{array}$ \\
\hline Analytical & OLAP & -Ability to support Ad hoc reporting (development of new reports & 3 \\
\cline { 3 - 5 } & & -Ability to support historical comparisons/trending & 3 \\
\cline { 3 - 4 } & & -Ability to perform drill down back to the source Data Base tables & 3 \\
\cline { 3 - 5 } & & -Ability to do ad hoc complex calculations (@ report level and cube level) & 3 \\
\hline
\end{tabular}

\section{Performance Measurement Perspective}

- The financial and non-financial indicators in the company are measured on a regular basic.

- The financial and non-financial performance data in the company is not fully automated.

- The performance data in the company is stored in an integrated IT system.
- The financial and non-financial performance results in the company are transmitted to the stakeholders electronically.

- The company has set the quantitative goals for the measurement process and each business unit has specific business target.

- The storage is managed at enterprise level.

Table 9: Company A’s Performance Measurement Perspective

\begin{tabular}{|c|c|c|c|}
\hline $\begin{array}{l}\text { Key process } \\
\text { area }\end{array}$ & Criteria & Appraisal Measures & $\begin{array}{l}\text { Capability levels } \\
\text { (Please Rate 0-5) }\end{array}$ \\
\hline \multirow[t]{5}{*}{$\begin{array}{l}\text { Performance } \\
\text { measurement }\end{array}$} & $\begin{array}{l}\text { Scope of } \\
\text { Measurement }\end{array}$ & $\begin{array}{l}\text { - Financial and non-financial } \\
\text { indicators are measured on a } \\
\text { regular basis. }\end{array}$ & 3 \\
\hline & Data collection & $\begin{array}{l}\text { - Collection of financial and non } \\
\text { financial performance data is } \\
\text { fully automated. }\end{array}$ & 2 \\
\hline & Storage of data & $\begin{array}{l}\text { - Performance data is stored in } \\
\text { an integrated IT system. }\end{array}$ & 2 \\
\hline & $\begin{array}{l}\text { Communication of } \\
\text { performance } \\
\text { results }\end{array}$ & $\begin{array}{l}\text { - Financial and non-financial } \\
\text { performance results are } \\
\text { transmitted to the stakeholders } \\
\text { electronically (push option) }\end{array}$ & 2 \\
\hline & $\begin{array}{l}\text { Use of the } \\
\text { measurement }\end{array}$ & $\begin{array}{l}\text { - Quantitative goals for the } \\
\text { measurement processes are set. }\end{array}$ & 3 \\
\hline
\end{tabular}




\section{Balanced Scorecard Perspective}

- $\quad$ The company's balanced scorecard is able to answer "How do we look to shareholders?"

- The company's balanced scorecard can get the feedback for clients.
- The company's balanced scorecard enables the company to view their performance on monthly and yearly basic.

- The company's balanced scorecard enables the company to continue improve based on the tread analysis.

Table 10: Company A's Balanced Scorecard Perspective

\begin{tabular}{|l|l|l|c|}
\hline \multicolumn{1}{|c|}{$\begin{array}{c}\text { Key process } \\
\text { area }\end{array}$} & \multicolumn{1}{|c|}{ Criteria } & \multicolumn{1}{c|}{ Appraisal Measures } & $\begin{array}{c}\text { Capability levels } \\
\text { (Please Rate 0-5) }\end{array}$ \\
\hline $\begin{array}{l}\text { Balanced } \\
\text { Scorecard }\end{array}$ & Financial & $\begin{array}{l}\text {-Ability to answer to the question } \\
\text { "How do we look to shareholders?" }\end{array}$ & 3 \\
\cline { 2 - 4 } & Customer & $\begin{array}{l}\text {-Ability to answer the question "How do } \\
\text { customers see us?" }\end{array}$ & 3 \\
\cline { 2 - 4 } & $\begin{array}{l}\text { Internal Business } \\
\text { Processes }\end{array}$ & $\begin{array}{l}\text {-Ability to answer the question "What must } \\
\text { we excel at?" }\end{array}$ & 3 \\
\cline { 2 - 4 } & $\begin{array}{l}\text { Learning and } \\
\text { Growth }\end{array}$ & -Ability to answer questions "Can we \\
continue to improve and create value? & \\
\hline
\end{tabular}

\section{Information Quality (IQ) Perspective}

- The company has a strategic value on data quality.

- The issue that affects data quality in the company is the source system is not integrated.

- In the company, respective head of department is responsible to ensure information quality.

- The data value of the company is quite close to the correct information.

- The company expects the data instances contain all the information they are supposed to.
- The company knows the importance the data accuracy across the organization.

- The data in the company is updated daily and near real time.

- Data definitions are standard across enterprise as it is resided in central server.

- There is inconsistency between data source across department or an enterprise.

- The company implements regular data cleansing, fine tuning of ETL rules. 
Table 11: Company A's Information Quality Perspective

\begin{tabular}{|l|l|l|c|}
\hline $\begin{array}{l}\text { Key process } \\
\text { area }\end{array}$ & Criteria & Appraisal Measures & $\begin{array}{l}\text { Capability levels } \\
\text { (Please Rate 0-5) }\end{array}$ \\
\hline $\begin{array}{ll}\text { Information } \\
\text { Quality }\end{array}$ & Accuracy & $\begin{array}{l}\text { - The degree to which data value agree } \\
\text { with an identified source of correct } \\
\text { information }\end{array}$ & 3 \\
\cline { 2 - 4 } & Completeness & $\begin{array}{l}\text {-The expectation that data instances } \\
\text { contain all the information they are } \\
\text { supposed to. }\end{array}$ & 3 \\
\cline { 2 - 4 } & Tonsistency & $\begin{array}{l}\text {-The degree to which information is in the } \\
\text { same format }\end{array}$ & 3 \\
\hline
\end{tabular}

\section{People Perspective}

- The company is pro-active in preparing the organization for the future.

- The company is able to ensure that staff understands the common vision and can translate it into terms relevant to their roles.

- The company seeks to recruit people with good information skills and the workforce contains a high percentage of knowledge workers.

- The company has a comprehensive training plan program that is scheduled and organized through whole year.

- The company has multidisciplinary team / cross functional peers group that come together to solve corporate issues.

- The overall level of analytical skill and proficiency in using BI software is advanced level.

- The current skill is set adequate to meet the information needs of the company but can be further improved.
- The company typically hires people with these skills or develops them with training programs.

- The employees in the company gain information skills through formal training.

- The company has information skills training programs through portal and email.

- All level of employee in the company has access to the training.

- The company makes overt efforts to attract and retain people with superior information skills.

- The leadership styles applied across the organization are empowerment, trust and mentor leadership.

- Teamwork is formalized within the organization and it is important to achieve company goal and targets. 
Table 12: Company A's People Perspective

\begin{tabular}{|c|c|c|c|}
\hline $\begin{array}{l}\text { Key process } \\
\text { area }\end{array}$ & Criteria & Appraisal Measures & $\begin{array}{l}\text { Capability } \\
\text { levels }\end{array}$ \\
\hline \multirow[t]{5}{*}{ People } & \multirow[t]{2}{*}{ Leadership } & $\begin{array}{l}\text {-Pro-active in preparing the organization } \\
\text { for the future }\end{array}$ & 4 \\
\hline & & $\begin{array}{l}\text {-Visible and engaged to ensure that } \\
\text { staff understands the common vision and } \\
\text { can translate it into terms relevant to their } \\
\text { roles }\end{array}$ & 4 \\
\hline & Skills & $\begin{array}{l}\text {-Seeks to recruit people with good } \\
\text { information skills and the workforce } \\
\text { contains a high percentage of knowledge } \\
\text { workers }\end{array}$ & 5 \\
\hline & Training & $\begin{array}{l}- \text { Comprehensive training plan } \\
\text { program is scheduled and organized. }\end{array}$ & 5 \\
\hline & Dynamic & $\begin{array}{l}\text { - Multidisciplinary team / cross functional } \\
\text { peers group come together to solve } \\
\text { corporate issues. }\end{array}$ & 4 \\
\hline
\end{tabular}

\section{Organization Culture Perspective}

- The company has compensation structure that rewards knowledge workers with high analytical skills and collaborative ability based on yearly appraisal key performance indicators (KPI).
- The environment of the company is very competitive.

- The people/staffs in the company start to think strategically and a lot of ideas and campaigns are being generated.

Table 13: Company A's Organization Culture Perspective

\begin{tabular}{|l|l|l|c|}
\hline $\begin{array}{l}\text { Key process } \\
\text { area }\end{array}$ & Criteria & Appraisal Measures & $\begin{array}{c}\text { Capability levels } \\
\text { (Please Rate 0-5) }\end{array}$ \\
\hline $\begin{array}{l}\text { Organization } \\
\text { Culture }\end{array}$ & Reward & $\begin{array}{l}\text {-The compensation structure rewards knowledge } \\
\text { workers with high analytical skills and collaborative } \\
\text { ability. }\end{array}$ & \\
\cline { 2 - 4 } & Attitude & $\begin{array}{l}\text {-The environment of companies is not competitive. } \\
\text { (- People are starting to think strategically and a lot } \\
\text { of ideas are being generated }\end{array}$ & 5 \\
\cline { 3 - 4 } & & 5 \\
\hline
\end{tabular}

\section{Strategic Management Perspective}

- The company is able to use consistent definitions of planning terms and understand their distinctions.
- The company is aware of the distinctions between project planning and strategic planning. 
- The staffs of the company at all levels are motivated by a common vision and strategy.

- The company defined any global BI goals which provide self optimizing capabilities to end users and move towards service orientation to maximize business growth.

- The company has individual goal that cascaded to the corporate or group goals.
- The company monitors their employee awareness of corporate goals through posters.

- The company uses dialogue and forum to ensure that people in the company understand strategic direction and the role they play in it.

Table 14: Company A's Strategic Management Perspective

\begin{tabular}{|c|c|c|c|}
\hline $\begin{array}{l}\text { Key process } \\
\text { area }\end{array}$ & Criteria & Appraisal Measures & $\begin{array}{l}\text { Capability } \\
\text { levels }\end{array}$ \\
\hline \multirow[t]{6}{*}{$\begin{array}{l}\text { Strategic } \\
\text { management }\end{array}$} & \multirow{4}{*}{$\begin{array}{l}\text { Strategic } \\
\text { thinking and } \\
\text { planning }\end{array}$} & $\begin{array}{l}\text { - Ability to use consistent definitions of planning terms and to } \\
\text { understand their distinctions }\end{array}$ & 4 \\
\hline & & $\begin{array}{l}\text {-Awareness of the distinctions between project planning and } \\
\text { strategic planning }\end{array}$ & 4 \\
\hline & & $\begin{array}{l}\text {-Ability to discuss and describe items in plans at the } \\
\text { appropriate "strategic altitude" }\end{array}$ & 4 \\
\hline & & $\begin{array}{l}\text {-Awareness of the dynamic system effects in organizations, such as } \\
\text { delays and feedback }\end{array}$ & 4 \\
\hline & Visions & -People at all levels are motivated by a common vision and strategy & 4 \\
\hline & Goals & $\begin{array}{l}\text { - Organization defined global BI goals which provide self- optimizing } \\
\text { capabilities to e nd users, and move towards service } \\
\text { orientation to maximize business growth. }\end{array}$ & 4 \\
\hline
\end{tabular}

\section{Change Management Perspective}

- The company implemented a change management program in recent years but in non formal way.

- The employees across the company understand change management, and how they play a role in making change successful.
- The majority of the employees in the company adapt to the changes.

- People are willing to change their roles and responsibilities.

- People are willing to support a change in company strategy. 
Table 15: Company A's Change Management Perspective

\begin{tabular}{|l|l|l|c|}
\hline $\begin{array}{l}\text { Key process } \\
\text { area }\end{array}$ & Criteria & \multicolumn{1}{|c|}{ Appraisal Measures } & $\begin{array}{l}\text { Capability levels } \\
\text { (Please Rate 0-5) }\end{array}$ \\
\hline $\begin{array}{l}\text { Change } \\
\text { Management }\end{array}$ & Adaptability & $\begin{array}{l}\text {-Employees across the enterprise understand } \\
\text { change management, why it is important to project } \\
\text { success and how they play a role in making change } \\
\text { successful. }\end{array}$ & 3 \\
\cline { 2 - 4 } & & -Employees can adapt to the change & 3 \\
\hline
\end{tabular}

\section{Conclusions and Future Works}

This paper proposes an EBI maturity model (EBI2M) to assist the organizations to identify the existing problems of BI implementation and plan a systematic path to evolve to higher levels of maturity. An EBI2M is evaluated through one of the financial companies. The result indicates that the company does not achieve highest maturity in terms of data warehouse, metadata management, knowledge management and performance measurement perspective.

\section{Acknowledgment}

The authors acknowledge the time and commitment of all participants in the case study.

\section{References}

Ang, J. \& Teo, T. S. H. (2000). “Management Issues in Data Warehousing: Insights from the Housing and Development Board," Decision Support Systems. 29(1): 11-20.

Carlo, V. (2009). 'Business Intelligence: Data Mining and Optimization for Decision Making,' Wiley.

Cates, J. E., Gill, S. S. \& Zeituny, N. (2005). "The Ladder of Business Intelligence (LOBI): A Framework for Enterprise IT Planning and Architecture," International Journal of Business Information system. 1(1): 220-238.
Chang, E. (2006). 'Advanced BI Technologies, Trust, Reputation and Recommendation Systems,' 7th Business Intelligence Conference (Organised by Marcus Evans), Sydney, Australia.

Computerworld. (2003). 'The Top 10 Critical Challenges for Business Intelligence Success,' Computer world.

Deng, R. (2007). "Business Intelligence Maturity Hierarchy: A New Perspective from Knowledge Management," Information Management. http://www.informationmanagement.com/ infodirect/20070323/1079089-1.html

Eckerson, W. (2004). “Gauge Your Data Warehouse Maturity," Information Management. viewed on 29. April 2009, <http://www.informationmanagement.com/issues/20041101/101239 1-1.html>.

Faherty, V. (1979). "Continuing Social Work Education: Results of a Delphi Surved," Journal of Education for Social Work. 15(1): 12-19.

Gartner Research. (2007). "Gartner EXP Survey of More than 1,400 CIOs Shows CIOs Must Create Leverage to Remain Relevant to the Business," Retrieved 01/04/2009, from $<$ http://www.gartner.com/it/page.jsp?id=50 1189>. 
Gartner Research. (2008). "Gartner EXP Worldwide Survey of 1,500 CIOs Shows 85 Percent of CIOs Expect Significant Change Over Next Three Years," Retrieved 01/04/2009, from <http://www.gartner.com/it/page.jsp?id=58 7309>.

Gartner Research. (2009). “Gartner EXP Worldwide Survey of More than 1,500 CIOs Shows IT Spending to Be Flat in 2009," Retrieved 01/04/2009, from <http://www.gartner.com/it/page.jsp?id=85 5612>.

Hagerty, J. (2006). “AMR Research's Business Intelligence/ Performance Management Maturity Model, Version 2," Viewed on 21 April 2009, <http://www.cognos.com/pdfs/analystrepor ts/ar_amr_researchs_bi_perf.pdf

Hewlett-Packard. (2007). 'The HP Business Intelligence Maturity Model,' Viewed on 21 April 2009. <http://h71028.www7.hp.com/ERC/downlo ads/4AA1-5467ENW.pdf

Hostmann, B. (2007). 'Business Intelligence Scenario,' Paper presented at the Gartner Business Intelligence Summit,

IDC. (2007). 'Top Ranked Business Intelligence Tools Vendors Maintain Positions,' Viewed 03 Jul 2007, <http://www.idc.com/getdoc.jsp?containerI $\mathrm{d}=$ prUS20767807>.

Juran, J. M., Gryna, F. M. J \& Bingham, R. S. (1974). 'Quality Control Handbook,' 3 edn, McGraw-Hill Book Co, New York, NY.

Kahn, B. K., Strong, D. M. \& Wang, R. Y. (2002). "Information Quality Benchmarks: Product and Service Performance," Communications of the ACM:184-192.

Kašnik, A. (2008). 'Odel Optimization Infrastructure,' Internal Material of ZRSZ, Ljubljana.
Ke, W. \& Wei, K. K. (2008). "Organizational Culture and Leadership in ERP Implementation," Decision support system: 208-218.

Loshin, D. (2003). 'Business Intelligence: The Savvy Manager's Guide,' Morgan Kaufmann Publishers/Elsevier, Boston.

Lupu, A. R., Bologa, R., Lungu, I. \& Bara, A. (2007). "The impact of Organization Changes on Business Intelligence Projects," Proceedings of the 7th WSEAS International Conference on Simulation, Modeling and Optimization, Beijing, China, September 1517: 414-418.

Moss, L. \& Atre, S. (2003). Business Intelligence Roadmap: The Complete Lifecycle for Decision-Support Applications, Addison-Wesley, Boston, MA.

Moss, L. T. \& Hoberman, S. (2004). 'The Importance of Data Modeling as a Foundation for Business Insight,'Teradata.

Rajterič, I. H. (2010). 'Overview of Business Intelligence Maturity Models,' International Journal of Human Science. 15(1): 47-67.

Raskin, M. S. (1994). "The Delphi Study in Field Instruction Revisited: Expert Consensus on Issues and Research Priorities," Journal of Social Work Education: 75-89.

Redman, T. C. (1998). "The Impact of Poor Data Quality on the Typical Enterprise," Communications of the ACM. 41(2): 79-82.

Richardson, J., Schlegel, K., Sallam, R. L. \& Hostmann, B. (2008). "Magic Quadrant for Business Intelligence Platforms," Gartner.

Sacu, C. \& Spruit, M. (2010). "BIDM: The Business Intelligence Development Model," Proceedings of the 12th International Conference on Enterprise Information Systems, Funchal, Madeira-Portugal. 
Simon, R. (2002). 'Performance Measurement and Control Systems for Implementing Strategy,' Prentice Hall.

Tayi, G. K. \& Ballou, D. P. (1998). "Examining Data Quality," Communications of the ACM. 41(2): 54-57.

Turban, E., Sharda, R., Aronson, J. E., \& King, D. (2011). 'Business Intelligence: A Managerial Approach,' Prentice Hall.

Turban, E. \& Volonino, L. (2010). 'Information Technology for Management: Transforming Organization In The Digital Economy,' Wiley.

Whitehorn, M. \& Whitehorn, M. (1999). Business Intelligence: The IBM Solution Data warehousing and OLAP, Springer-Verlag, NY.

William, S. \& William, N. (2007). "The Profit Impact of Business Intelligence," Morgan Kaufmann Publishers, San Francisco. 